\title{
Discrimination of stable isotopes in fin whale tissues and application to diet assessment in cetaceans
}

Short title: Diet-tissue discrimination factors in fin whale

\begin{abstract}
A. Borrell, N. Abad Oliva, E. Gómez-Campos, J. Giménez and A. Aguilar Biodiversity Research Institute (IrBio) and Department of Animal Biology, Faculty of Biology, University of Barcelona, Av. Diagonal, 643 (08028) Barcelona, Spain
\end{abstract}

Corresponding author
A. Borrell,
Department of Animal Biology, Faculty of Biology, University of Barcelona, Av. Diagonal, 643 (08028) Barcelona, Spain
tel: +34934021453
fax: +34934034426
e-mail: xonborrell@ub.edu. 
RATIONALE: In stable isotopes research, the use of accurate, species-specific diet-tissue discrimination factors (i.e., $\Delta^{13} \mathrm{C}$ and $\Delta^{15} \mathrm{~N}$ ) is central to estimate trophic position relative to primary consumers and to identify the dietary sources of an individual. Previous research suggested that the diet of fin whales from the waters off northwestern Spain is overwhelmingly based on krill, a trait that permits reliable calculation of discrimination values in this wild population.

METHODS: After confirming that stable isotope ratios $\left(\delta^{13} \mathrm{C}\right.$ and $\left.\delta^{15} \mathrm{~N}\right)$ in muscle from 65 aged fin whales remained constant through age classes (4-65 years), we analyzed signatures in muscle, bone protein, skin, liver, kidney, baleen plates and brain, as well as food (krill), from a subset of individuals to calculate discrimination factors. Signatures were determined by means of elemental analysis isotope ratio mass spectrometry (EA-IRMS) using a ThermoFinnigan Flash 1112.

RESULTS: Isotopic values remained constant regardless of age. The mean $\Delta^{15} \mathrm{~N}$ values between krill and whale tissues ranged from 2.04 in bone protein to $4.27 \%$ in brain, and those of $\Delta^{13} \mathrm{C}$ ranged from 1.28 in skin to $3.11 \%$ in bone protein. This variation was consistent with that found in other groups of mammals, and is attributed to variation in tissue composition and physiology.

CONCLUSIONS: Because discrimination factors are relatively constant between taxonomically close species, the results here obtained may be reliably extrapolated to other cetaceans to improve dietary reconstructions. The skin discrimination factors are of particular relevance to monitoring diet through biopsies or other non-destructive sampling methods. The large difference of bone protein discrimination factors when compared to other tissues should be taken into consideration when bone collagen is used to determine trophic level or to assess diet in paleodietary isotopic reconstructions.

Key words: $\delta^{15} \mathrm{~N}, \delta^{13} \mathrm{C}$, diet, cetacean, Balaeoptera physalus, Spain, 


\section{INTRODUCTION}

Stable isotopes of carbon $\left(\delta^{13} \mathrm{C}\right)$ and nitrogen $\left(\delta^{15} \mathrm{~N}\right)$ have been widely used to study the diet, trophic interactions, migratory patterns, and habitat use of mammals and other vertebrates. To a lesser extent, stable isotopes have also been used to investigate physiological processes, such as nutritional stress and those associated with reproductive biology. ${ }^{[1]}$

It is possible to use stable isotopes to study diet, and infer trophic relationships among species, because the isotopic composition of animal tissues is directly related to the isotopes present in their food resources. ${ }^{[2,3]}$ Typically, the $\delta^{15} \mathrm{~N}$ signature increases between $2 \%$ and $4 \%$ at each trophic level, usually varying among tissues and species. ${ }^{[4,5]}$ In comparison, $\delta^{13} \mathrm{C}$ values show little or no consistent variation with increasing trophic level; ${ }^{[6]}$ however, this value is primarily related to ecological divisions within aquatic systems. For instance, inshore, benthic, and coastal sources tend to be ${ }^{13} \mathrm{C}$ enriched (higher $\delta^{13} \mathrm{C}$ ) compared to offshore or pelagic sources. ${ }^{[7,8,9]}$

Discrimination factors between the consumer and food source $\left(\Delta^{3} C\right.$ and $\Delta^{15} \mathrm{~N}$; also termed fractionation factors) are calculated as the differences between the isotopic signal of consumer tissue and those of its food source. ${ }^{[10}$,

${ }^{11]}$ Caut et al. ${ }^{[5]}$ summarized the three main causes of variation in the magnitude of the discrimination: 1) diet composition: lipids, proteins, carbohydrates, and the different forms in which each of these components may occur in diet are metabolized in different ways, thus affecting isotope discrimination; 2) tissue type: the composition of different consumer tissues determines differential isotopic routing and assimilation; 3) taxon: different species present different discrimination factors, due to variation in excreted nitrogen and metabolic rate among other species-specific variables.

The use of accurate, species-specific diet-tissue discrimination factors is one of the most important basic requirements when applying stable isotope mixing models to predict the dietary sources of a consumer ${ }^{[11]}$. In addition, they are also required to estimate species trophic position relative to primary consumers ${ }^{[11]}$. Current knowledge about patterns of isotopic discrimination $\left(\Delta^{3} \mathrm{C}\right.$ and $\Delta^{15} \mathrm{~N}$ ) on marine mammals, particularly cetaceans, remains limited. ${ }^{[12]} \Delta^{3} \mathrm{C}$ and $\Delta^{15} \mathrm{~N}$ are known for certain species (some pinnipeds and odontocetes) that are able to live in captivity, with values being supported by experimental feeding using a controlled and constant diet during the required period for tissues to acquire the new isotopic signal. This period, often termed "turn over," may range from days to months or years, depending on the metabolic activity of the tissues that are involved. ${ }^{[5,12]}$ To our knowledge, less than 10 studies have been carried on diet-tissue discrimination in marine mammals, ${ }^{[11]}$ with only one of these on cetaceans ${ }^{[13]}$ and none on whales. Furthermore, these studies were primarily mainly conducted on a few tissues, such as fur, vibrissa, or blood components.

The diet of fin whales (Balaenoptera physalus) inhabiting the Atlantic ocean off northwestern Spain is known to be primarily dependent on the euphausiid krill, Meganyctiphanes norvegica (hereafter krill). ${ }^{[14,15]}$ Moreover, this species was exploited in their foraging area for over 30 years (1951-1985) by three whaling factories located in Galicia, on the northwestern coast of Spain. ${ }^{[16]}$ During the 1980s, we sampled captured whales, and examined their stomach 
contents, which exclusively contained krill. ${ }^{[17]}$ Hence, because the diet of this population appeared stable, we considered it an ideal species to study isotopic discrimination between its tissues and dietary source in a wild population.

The objectives of the present study were to: 1) demonstrate the absence of ontogenetic variation in the food resources of fin whales, by analyzing differences in the isotopic signatures of their tissues related to age, and 2) determine the stable isotope discrimination of different fin whale tissues, to obtain valid values that could be applied to isotopic dietary studies of other taxonomically close species.

\section{MATERIALS AND METHODS}

During the 1983-1985 whaling seasons, samples of fin whales were obtained at the Caneliñas whaling station, which is situated on the northwestern coast of Spain.

Muscle samples, from the region posterior to the dorsal fin, and ear-plug cores were collected from 65 individuals. The ear-plug samples were preserved in $10 \%$ formaldehyde until being used to determine the age of whales in the laboratory. Muscle samples, and other tissue samples, were wrapped in aluminum foil, and preserved at $-20 \stackrel{\circ}{\mathrm{C}}$ until analysis.

In addition, skin, bone, liver, kidney, muscle, and brain samples were collected from 11 individuals (7 males and 4 females) (Table 1). Furthermore, 5 baleen plates and 10 krill samples from stomach content were collected from other 15 fin whales in 1985.

\section{Age determination}

Age was determined by counting the growth layers present on a longitudinal section of the ear-plug core, according to the procedure described by Aguilar and Lockyer. ${ }^{[18]}$ Each plug was assessed by more than one researcher, with approximately $70 \%$ of plugs being read twice by the same researcher. Where different values were obtained in multiple readings, the average of all age estimates was used, unless the difference between the readings was greater than $10 \%$ of the lowest reading, in which case the specimen was not used in subsequent calculations.

\section{Stable isotope analyses}

Approximately $1 \mathrm{~g}$ of tissue (except for bone) was subsampled from each sample, dried for $48 \mathrm{~h}$ at $60^{\circ} \mathrm{C}$, and then ground to a powder with a mortar and pestle. Since lipids may bias the analyses by decreasing $\delta^{13} \mathrm{C}$ levels ${ }^{[2]}$, they were removed from the samples sequentially soaking samples in a chloroform:methanol (2:1) solution, and shaking them with a rotator to accelerate lipid content extraction.

Bone was separated into two subsamples. One subsample was treated with a $0.5 \mathrm{M} \mathrm{HCl}$ solution, to eliminate inorganic carbonates and obtain protein isotope signatures. ${ }^{[19,20]}$ The second subsample was analyzed without $\mathrm{HCl}$ treatment, to prevent alterations in nitrogen signatures. However, comparison 
between methodologies showed that isotope ratios did not differ between demineralized and untreated samples.

Approximately $0.5 \mathrm{mg}$ of powdered samples was weighed into tin capsules, automatically-loaded and combusted at $1000^{\circ} \mathrm{C}$ to be analysed in a continuous flow isotope ratio mass spectrometer (Flash 1112 IRMS Delta C Series EA Thermo Finnigan). Analyses were performed at the ScientificTechnical Services of the University of Barcelona.

The abundance of stable isotope was expressed in delta $(\delta)$ notation, while the relative variations of stable isotope ratios were expressed as permil (\%o) deviations from the predefined international standards as:

$$
\delta X=\left[\left(R_{\text {sample }} / R_{\text {standard }}\right)-1\right] \times 1000,
$$

where $X$ is ${ }^{13} \mathrm{C}$ or ${ }^{15} \mathrm{~N}$, and $R_{\text {sample }}$ and $R_{\text {standard }}$ are the ${ }^{13} \mathrm{C} /{ }^{12} \mathrm{C}$ and ${ }^{15} \mathrm{~N} /{ }^{14} \mathrm{~N}$ ratios in the sample and standard, respectively. The standards used were Vienna Pee Dee Belemnite (V-PDB) calcium carbonate for ${ }^{13} \mathrm{C}$ and atmospheric nitrogen (air) for ${ }^{15} \mathrm{~N}$. International secondary standards provided by the International Atomic Energy Agency (IAEA) were inserted after every 12 samples, to calibrate the system and compensate for any drift over time. Precision and accuracy for $\delta^{13} \mathrm{C}$ and $\delta^{15} \mathrm{~N}$ measurements were $0.1 \%$ and $0.3 \%$, respectively.

\section{Calculation of diet-tissue discrimination}

Diet-tissue discrimination denotes the difference in isotopic composition between a consumer and its diet. We calculated the diet-tissue discrimination factor as:

$$
\Delta X_{\text {tissue-diet }}=\delta X_{\text {tissue }}-\delta X_{\text {krill }}
$$

where $\mathrm{X}$ is ${ }^{13} \mathrm{C}$ or ${ }^{15} \mathrm{~N}$. The notation $\Delta \mathrm{X}$ tissue-diet was abbreviated to $\Delta \mathrm{X}$ in this study. Because consumers are typically enriched in the heavy isotope relative to diet, such discrimination values are generally positive, with some exceptions in $\Delta^{13} \mathrm{C}$, probably due to rich lipid diets. ${ }^{[21]}$

\section{Data analyses}

The data were first checked for the occurrence of possible outliers. Out of 142 datapoints in total, three $\delta^{15} \mathrm{~N}$ values (those of bone protein from whale 1 and of brain and skin from whale 4; table 1) were treated as outliers, which comprised values differing by at least three standard deviations from the overall tissue mean. These values were excluded from the analysis.

The normality and homoscedasticity of the data were tested using Kosmogorov-Smirnov and Levene's tests, respectively. All groups followed a normal distribution, and presented homogeneity of variances.

Regression analyses were performed to assess the relationship between $\delta^{15} \mathrm{~N}$ and $\delta^{13} \mathrm{C}$ values and age.

GLMs (general linear models) with individual identity (individual as a random factor) and tissue as a fixed factor were used to test differences in discrimination factors $\left(\Delta^{15} \mathrm{~N}\right.$ and $\left.\Delta^{13} \mathrm{C}\right)$ among tissues. Following a significant 
fixed effect, differences between tissue types were analyzed by a Post Hoc Tukey's pairwise comparisons test. All statistical calculations were carried out using the statistical package SPSS15 (SPSS Inc.).

\section{RESULTS}

\section{Age-related variations in $\delta^{15} \mathrm{~N}$ and $\delta^{13} \mathrm{C}$ values}

The estimated age range based on ear-plug readings was 4 to 65 years. The $\delta^{15} \mathrm{~N}$ values in fin whale muscle ranged from $8.15 \%$ o to $11.03 \%$, while the $\delta^{13} \mathrm{C}$ values ranged from $-17.43 \%$ o to $-19.29 \%$.

No relationship between $\delta^{15} \mathrm{~N}\left(R^{2}=0.060, p=0.076\right)$ or $\delta^{13} \mathrm{C}\left(R^{2}=0.001\right.$, $p=0.850$ ) values and the age of the individuals was observed (Fig. 1).

\section{Discrimination between fin whale tissues and krill}

The $\delta^{15} \mathrm{~N}$ values of fin whale ranged from $8 \%$ in bone protein to $11.9 \%$ in the brain, whereas the $\delta^{13} \mathrm{C}$ values ranged from $-19 \%$ in muscle and liver to -16 $\%$ in bone protein.

As krill was identified as the sole diet of fin whale, diet-tissue discrimination was always calculated relative to the delta values of krill. The $\delta^{15} \mathrm{~N}$ values in krill ranged from $5.12 \%$ to $8.48 \%$ ( $n=10$, mean \pm SD: $7.15 \pm$ $1.10 \%$ ), while the $\delta^{13} \mathrm{C}$ values ranged from $-18.56 \%$ o to $-20.02 \% \quad(n=10$, mean \pm SD: $-19.57 \pm 0.47 \%$ ). $\Delta^{15} \mathrm{~N}$ ranged from $0.85 \%$ in bone protein to 4.75 $\%$ in brain, whereas $\Delta^{13} \mathrm{C}$ ranged from $0.57 \%$ in muscle and liver to $3.57 \% \circ$ in bone protein (Fig. 2). Table 2 presents the mean stable isotope and diet-tissue discrimination values for each tissue type.

GLMs indicated that both tissue $(p<0.001)$ and individual $(p<0.001)$ affected $\Delta^{15} \mathrm{~N}$, with a non-significant interaction term $(\mathrm{p}=0.122)$. Figure 2 shows the relationship of each discrimination factor per individual and tissue. $\Delta^{15} \mathrm{~N}$ in fin whale was highly different among tissues, ranking brain $>$ liver $>$ kidney $>$ skin $>$ baleen $>$ muscle $>$ bone protein (Table 2, Fig. 2). Pairwise differences between tissues are presented in Table 3.

GLMs indicated that both tissue $(p<0.001)$ and individual $(p<0.01)$ affected $\Delta^{13} \mathrm{C}$, with a non-significant interaction term $(p=0.292) . . \Delta^{13} \mathrm{C}$ values in fin whale ranked: bone protein $>$ baleen $>$ brain $>$ liver $>$ kidney $>$ muscle $>$ skin (Table 2 , Fig. 2). Pairwise differences between tissues are presented in Table $3 . \Delta^{13} \mathrm{C}$ in bone protein was significantly higher compared to all other tissues. Skin and muscle showed the lowest levels of $\Delta^{13} \mathrm{C}$, which differed to the brain and baleen. Those of liver and kidney only differed to bone protein.

\section{DISCUSSION}

As anticipated, the stable isotope ratios of muscle did not change with age for animals older than 4 years, thus indicating no ontogenic dietary change in fin whales after that age.. We could not evaluate younger individuals because yearlings and calves were not caught in commercial whaling operations, as a protocol to minimize threat to the population. In theory, calves should present 
higher $\delta^{15} \mathrm{~N}$ values compared to older age groups, due to their receiving milk nourishment from their mothers, which is typical for most mammals. ${ }^{[22-25]}$

Differences in isotopic signatures related to age have been documented for several marine mammals, including pinnipeds, ${ }^{26,27]}$ odontocetes, ${ }^{[28]}$ and even baleen whales. ${ }^{[29.30]}$ These differences have generally been attributed to ontogenetic dietary shifts due to variations in feeding area or in habitat use, or in the nutritional requirements of the individual throughout its lifespan. The lack of ontogenetic variations in $\delta^{13} \mathrm{C}$ values reinforces that fin whales inhabiting the Atlantic ocean off northwestern Spain consistently aggregate at the same summer foraging grounds, as previously suggested. ${ }^{[15]}$ However, the larger $\delta^{13} \mathrm{C}$ variability in whales younger than 15 years relative to that of older whales may reflect a wider geographical dispersion of younger whales in the feeding grounds.

Similarly, the consistency of $\delta^{15} \mathrm{~N}$ values with age shows that fin whales forage on the same prey throughout their life span, in agreement with stomach content analysis ${ }^{[31,32]}$ and observations of feeding aggregations. ${ }^{[33]}$

Moreover, the $\delta^{15} \mathrm{~N}$ signature in krill $(7.15 \% \circ \pm 1.10)$ showed that krill is located one trophic level below fin whales (mean of all tissues $10.27 \% \pm 0.9$ ). This result verifies that krill is the major dietary source for fin whales, which supports existing of stomach contents and diet studies of these animals. ${ }^{[14,31-33]}$ Thus, the results obtained in the present study reflect a diet-tissue isotope enrichment of $2-4 \%$ in $\delta^{15} \mathrm{~N}$ values and of $1-3 \%$ in $\delta^{13} \mathrm{C}$ values (Table 2). These ranges are similar to estimates of overall trophic-level enrichment in aquatic and terrestrial food webs. ${ }^{[2,3,4,6,8,22,34,35]}$

Isotope discrimination between consumer tissues and its dietary source has been extensively used to reconstruct diets. However, the absence of studies quantifying factors that might potentially alter these values has resulted in researchers generally using fixed global mean discrimination factors, which are obtained from published reviews that mix different tissues and consumer classes. The use of such datasets potentially cause biased results in dietary studies $^{[5,10]}$ that might be easily resolved using more adequate discriminating factors, depending on the species or tissue.

Caut et al. ${ }^{[5]}$ reviewed available isotope discrimination factors in different species, and analyzed the causes that influence this discrimination. The authors found that tissue type and consistency, diet, and consumer taxonomic group were the most important factors that contributed to its variation. In the current study, we focused on discrimination differences among fin whale tissues. Other factors may also influence the magnitude of tissue-diet discrimination, such as protein quantity or quality in the diet, form of nitrogen excretion, or other species-specific differences. However, these factors did not affect the results and interpretations of the present study, because they remained constant as we used tissues of just one species that had a stable dietary source (i.e., krill).

Previous studies have identified that differences in diet-tissue discrimination may arise due to the consistency (or nature) of consumer tissue being evaluated. $[5,10,12,13,36-38]$ Tissue nature is primarily the biochemical composition of proteins and lipids, along with metabolic properties. Generally, lipids are ${ }^{13} \mathrm{C}$ depleted, ${ }^{[2,39,40]}$ and tissues rich in fat content have lower $\delta^{13} \mathrm{C}$ discrimination compared to those with lower fat content. To avoid the influence 
of lipids in $\delta^{13} \mathrm{C}$ values, we extracted lipid from tissues, following general recommendations. ${ }^{[41]}$ However, differences in the protein composition (i.e., different proteins contain distinct proportions of amino acids) and metabolic routing of dietary components among tissue types may yield dissimilar isotopic compositions, irrespective of other factors. ${ }^{[10,11]}$ For example, the $\delta^{13} \mathrm{C}$ and $\delta^{15} \mathrm{~N}$ values of different amino acids in a single tissue may vary by more than $15 \%$. [42]

The tissue-diet discrimination values found in fin whale revealed consistent differences among tissues, which were comparable to those reported for other mammals. The results of a review by Caut et al. ${ }^{[5]}$ showed that mean tissue $\Delta^{15} \mathrm{~N}$ values in mammals ranked: plasma $(3.8 \%$ ) > entire blood $(3.6 \%$ ) $>$ liver $(3.3 \%$ ) $>$ muscle $(2.7 \%$ ) $>$ hair $(2.5 \%)>$ red blood cells $(2.1 \% \circ)$. The coincident tissues analyzed in the current study were liver and muscle, which ranked similarly to that showed previously; liver $(3.9 \%$ ) $>$ muscle $(2.7 \%$ ). Unfortunately, we did not collect fin whale hair (because whales have very little) or blood for comparison. However, Hobson et al. ${ }^{[12]}$ found that the red blood cells of seals was the tissue with lowest $\Delta^{15} \mathrm{~N}(1.7 \%$ ). They suggested that this low value might be the result of the high hemoglobin and hematocrit levels in the blood of diving mammals. Furthermore, $\Delta^{15} \mathrm{~N}$ in bottlenose dolphin (Tursiops truncatus) and in killer whale (Orcinus orca) red blood cells showed lower levels $(0.7 \%$ and $1.4 \%$ respectively) compared to plasma $(2.6 \%$ and $2.3 \%$ respectively). ${ }^{[13]}$ To our knowledge, besides these two species and associated tissue samples, other discrimination factors are not available for cetaceans.

In the current study, fin whale bone protein $\Delta^{15} \mathrm{~N}(2.03 \%)$ values were significantly lower as compared to all other tissues. They were twofold lower compared to the brain (4.27\%). Skin, baleen, and muscle $\left(\Delta^{15} \mathrm{~N} \approx 2.8 \%\right)$ showed very similar $\Delta^{15} \mathrm{~N}$ values, all of which were higher than bone protein. The similarity in both discrimination factors $\left(\Delta^{15} \mathrm{~N}\right.$ and $\left.\Delta^{13} \mathrm{C}\right)$ between skin and muscle indicates that skin may serve as an adequate tissue in place of muscle in studies that use stable isotopes. This is particularly important when following non-destructive approaches to investigate feeding ecology. However, the utility of skin should be evaluated by comparing the stable isotope ratios between skin and muscle in other cetacean species (even though discriminations have not yet been calculated). For instance, $\delta^{15} \mathrm{~N}$ and $\delta^{13} \mathrm{C}$ values are similar between muscle and epidermis in beluga whales (Delphinapterus leucas); however, $\delta^{15} \mathrm{~N}$ is significantly higher in the skin of bowhead (Balaena mysticetus) and gray whales (Eschrichtius robustus) compared to muscle, whereas $\delta^{13} \mathrm{C}$ was similar for the two tissue types in both species, ${ }^{[30]}$ and for humpback whales (Megaptera novaeangliae). ${ }^{[43]}$

Fin whale brain exhibited the highest estimate of $\Delta^{15} \mathrm{~N}(4.51 \%$ o). This value was similar to that $\left(4.78 \%\right.$ ) reported by Vanderklift and Ponsard ${ }^{[38]}$ for mice and rats. This high value is possibly due to the nature of the cerebral proteins. Liver and kidney had the next highest values, and were very similar to one another (Table 3). In mammals, $\Delta^{15} \mathrm{~N}$ in liver is often higher than in other tissues ${ }^{[5,12,38]}$, which has been attributed to its high metabolic activity. Kidney is not usually analyzed in mammals; therefore, there are no comparative references available.

Although the majority of fin whale tissues showed only minor $\Delta^{13} \mathrm{C}$ enrichment (1-2\%०) compared to the dietary source (krill), differences among 
tissues were important. Bone protein had significantly higher values compared to all other tissues (Table 3). This parameter was twofold higher $(3.11 \%$ ) compared to most tissue types, except brain (2.22\%o) and baleen (2.26\%o). These values support those found in other mammals. ${ }^{[5]} \mathrm{Koch}^{[1]}$ explained that the high $\Delta^{13} \mathrm{C}$ discrimination in collagen (principal bone protein) is due to its distinctive amino acid composition, i.e. collagen contains $33 \%$ glycine, a ${ }^{13} \mathrm{C}$ enriched aminoacid (+8\%) which implies it to be enriched relative to other tissues ${ }^{[44]}$. The large variation between bone protein and other tissues with respect to $\Delta^{13} \mathrm{C}$ and $\Delta^{15} \mathrm{~N}$ should also be considered in paleodietary isotopic reconstructions, for which bone is often used. ${ }^{[19]}$

Aside from collagen, the integument generally shows the highest $\Delta^{13} \mathrm{C}$ relative to other tissues in mammals. ${ }^{[2,12,45-47]}$ Hair, whiskers, nails, skin and baleen are all keratinized tissues that have similar biochemical composition. Hobson et al. ${ }^{[12]}$ found that some of these tissue types in seals have relatively high $\Delta^{13} \mathrm{C}\left(2.8-3.2 \%\right.$ ). Similarly, Tieszen et al. ${ }^{[45]}$ reported that hair had the highest $\Delta^{13} \mathrm{C}$ among tissues examined in laboratory gerbils raised on a monotonous diet.

In the current study, baleen plates had a significantly higher $\Delta^{13} \mathrm{C}$ value compared to muscle, based on biochemical composition. However, a much lower $\Delta^{13} \mathrm{C}$ value $(1.28 \%$ o) in skin was recorded than that expected, compared to that reported for keratinized tissues by Hobson et al. ${ }^{[12]}$. The $\Delta^{13} \mathrm{C}$ value of whale skin was similar to that of muscle, kidney, and liver (Table 3). Observed differences in skin $\Delta^{13} \mathrm{C}$ between cetaceans and other mammals may be due to large differences in skin composition. Some previous data supports these results. For instance, Horstmann-Dehn et al. ${ }^{[30]}$ found no differences in the $\delta^{13} \mathrm{C}$ values of muscle and skin of three Arctic cetaceans (i.e., bowhead, gray, and beluga whales). Similarly, Todd et al. ${ }^{[4]}$ found no significant difference in the $\delta^{13} \mathrm{C}$ values for the muscle and epidermis of humpback whales (Megaptera novaeangliae).

Therefore, additional studies are needed to discern whether the low $\Delta^{13} \mathrm{C}$ value of cetacean skin is a generalized result. The acquisition of such information is important because skin can be easily obtained of free ranging wild animals through biopsy sampling, a non-destrucitive technique. ${ }^{[44]}$

\section{CONCLUSIONS}

Given that discrimination factors are relatively constant between taxonomically close species, the results of the current study on fin whales may be extrapolated to other cetaceans to improve dietary reconstructions. Attention should be focused on the discrimination factors of skin (not previously available), which are of particular relevance towards monitoring diet through non-destructive biopsy sampling techniques. Furthermore, the large difference of bone protein discrimination factors as compared to other tissues should be taken into consideration when bone collagen is used to determine trophic level or to assess diet in paleodietary isotopic reconstructions. 


\section{REFERENCES}

(1) P. L. Koch. Isotopic study of the biology of modern and fossil vertebrates. in: Stable Isotopes in Ecology and Environmental Science (Eds: R. Michener, K. Lajtha) Blackwell Publishing, Boston, 2007, p 99.

(2) M. J. DeNiro, S. Epstein. Influence of diet on the distribution of carbon isotopes in animals. Geochim. Cosmochim. Acta 1978, 42, 495.

(3) M. J. DeNiro, S. Epstein. Influence of diet on the distribution of nitrogen isotopes in animals. Geochim. Cosmochim. Acta 1981, 45, 341.

(4) J. F. Kelly. Stable isotopes of carbon and nitrogen in the study of avian and mammalian trophic ecology. Can. J. Zool. 2000, 78, 1.

(5) S. Caut, E. Angulo, F. Courchamp. Variation in discrimination factors $\left(\Delta^{15} \mathrm{~N}\right.$ and $\Delta^{13} \mathrm{C}$ ): the effect of diet isotopic values and applications for diet reconstruction. J. App. Ecol. 2009, 46, 443.

(6) M. J. Vander Zanden, J. B. Rasmussen. Variation in $\delta^{15} \mathrm{~N}$ and $\delta^{13} \mathrm{C}$ trophic fractionation: Implications for aquatic food web studies. Limnol. Oceanogr. 2001, 46, 2061.

(7) D. R. Rubenstein, K. A. Hobson. From birds to butterflies: animal movement patterns and stable isotopes. Trend Ecol. Evolut. 2004, 19, 256.

(8) B. Fry. Food web structure on Georges Bank from stable C, N and S isotopic compositions. Limnol. Oceanogr.1988, 33, 1182.

(9) L. Cardona, M. Revelles, M.Sales, A. Aguilar, A. Borrell. Meadows of the seagrass Posidonia oceanica are a significant source of organic matter for adjoining ecosystems. Mar. Ecol. Prog. Ser. 2007, 335,123.

(10) C. Martínez del Rio, N. Wolf, S. A Carleton, L. Z. Gannes. Isotopic ecology ten years after a call for more laboratory experiments. Biol. Rev. 2009, 84, 91.

(11) S. D. Newsome, M. T. Clementz, P. L. Koch. Using stable isotope biogeochemistry to study marine mammal ecology. Mar. Mammal Sci. 2010, 26, 509.

(12) K. A. Hobson, D. M. Schell, D. Renouf, E. Noseworthy. Stable carbon and nitrogen isotopic fractionation between diet and tissues of captive seals: implications for dietary reconstructions involving marine mammals. Can. J. Fish. Aquat. Sci. 1996, $53,528$.

(13) S. Caut, S. Laran, E. Garcia-Hartmann, K. Das. Stable isotopes of captive Cetaceans (killer whales and bottlenose dolphins). J. Exp. Biol. 2011, 214, 538.

(14) S. Mizroch, A. Dale, W. Rice, J.M. Breiwick. The Fin Whale, Balaenoptera physalus. Mar. Fish. Rev. 1984, 46, 21.

(15) A. Aguilar. Fin Whale, Balaenoptera physalus, in Encyclopedia of Marine Mammals. (Eds: W. F. Perrin, B. Würsig, J. G. M. Thewissen), Elsevier-Academic Press. Amsterdam, Holanda, 2009, pp. 433-437.

(16) C. Sanpera, A. Aguilar. Modern whaling off the Iberian Peninsula during the 20th Century. Rep. int. Whal. Commn. 1992, 42, 723.

(17) A. Aguilar. PhD thesis, University of Barcelona, Barcelona, Spain, 1984.

(18) A. Aguilar, C. H. Lockyer,. Growth, physical maturity and mortality of fin whales (Balaenoptera physalus) inhabiting the temperate waters of the north-east Atlantic. Can. J. Zool. 1987, 65, 253.

(19) H. Bocherens, D. Billiou, M. Patou-Mathis, D.Bonjean, M. Otte, A. Mariotti. Paleobiological implications of the isotopic signatures $\left({ }^{13} \mathrm{C},{ }^{15} \mathrm{~N}\right)$ of fossil mammal 
collagen in Scladina Cave (Sclayn, Belgium). Quat. Res. 1997, 48, 370.

(20) S. D. Newsome, P. L. Koch, M. A. Etnier, D. Aurioles-Gamboa. Using carbon and nitrogen isotope values to investigate maternal strategies in northeast pacific otariids. Mar. Mammal Sci. 2006, 22, 556.

(21) G. B. Nardoto, P. B. Godoy, E. S. B. Ferraz, J. P. H. B. Ometto, L. A. Martinelli Stable carbon and nitrogen isotopic fractionation between diet and swine tissues. Sci. Agric. 2006, 63, 582.

(22) K. A. Hobson, J. L. Sease, R. L. Merrick, J. F. Piatt. Investigating trophic relationships of pinnipeds in Alaska and Washington using stable isotope ratios of nitrogen and carbon. Mar. Mammal Sci. 1997, 13, 114.

(23) K. A. Hobson, J. L. Sease. Stable isotope analyses of tooth annuli reveal temporal dietary records: an example using Steller sea lions. Mar. Mammal. Sci. 1998, 14, 116.

(24) M.L. Fogel, N. Tuross, D.W. Owsley. Nitrogen isotope tracers of human lactation in modern and archeological populations. Annual Report Geophysical Laboratory, Carnegie Institution 1988-1989. Geophysical Laboratory, Carnegie Institution, Washington, D.C., pp 111-117, 1989.

(25) K. A. Hobson, B. N. McLellan, J. G. Woods. Using stable carbon $\left(\delta^{13} C\right)$ and nitrogen $\left(\delta^{15} \mathrm{~N}\right)$ isotopes to infer trophic relationships among black and grizzly bears in the upper Columbia River basin, British Columbia. Can. J. Zool. 2000, 78, 1332.

(26) J. W. Lawson, K.A. Hobson. Diet of harp seals (Pagophilus groenlandicus) in nearshore Northeast Newfoundland: inferences from stable-carbon $\left(\square^{13} \mathrm{C}\right)$ and nitrogen $\left(\square^{15} \mathrm{~N}\right)$ isotope analyses. Mar. Mammal Sci. 2000, 16, 578.

(27) M. Drago, L.Cardona, E.A. Crespo, A. Aguilar. Ontogenic dietary changes in South American sea lions. J. Zool. 2009, 279, 251.

(28) E. Gómez-Campos, A. Borrell, L. Cardona, J. Forcada, A. Aguilar. Overfishing of small pelagic fishes increases trophic overlap between immature and mature striped dolphins in the Mediterranean. PLOS ONE 2011, 6, e24554.

(29) S. H. Lee, D. M. Schell, T. L. McDonald, W. J. Richardson. Regional and seasonal feeding by bowhead whales Balaena mysticetus as indicated by stable isotopes. Mar Ecol. Prog. Ser. 2005, 285, 271.

(30) L.Horstmann-Dehn, E. H. Follmann, C. Rosa, G. Zelensky, C. George. Stable carbon and nitrogen isotope ratios in muscle and epidermis of arctic whales. Mar. Mammal Sci. 2011, DOI: 10.1111/j.1748-7692.2011.00503.x.

(31) P. F. Brodie, D. D. Sameoto, R. W. Sheldon. Population densities of euphausiids off Nova Scotia as indicated by net samples, whale stomach contents, and sonar. Limnol. Oceanogr. 1978, 23, 1264.

(32) R.D. Flinn, A. W. Trites, E. J. Gregr, R.I. Perry. Diets of fin, sei, and sperm whales in British Columbia: an analysis of commercial whaling records, 1963-1967. Mar. Mammal Sci. 2002, 18, 663.

(33) F. Visser, K. L. Hartman, G. J. Pierce, V. D. Valavanis, J. Huisman. Timing of migratory baleen whales at the Azores in relation to the North Atlantic spring bloom. Mar. Ecol. Prog. Ser. 2011, 440, 267

(34) M. J. Schoeninger, M. J. DeNiro. Nitrogen and carbon isotopic composition of bone collagen from marine and terrestrial animals. Geochim. Cosmochim. Acta 1984, 48, 625. 
(35) D. M. Post. Using stable isotopes to estimate trophic position: models, methods, and assumptions. Ecology 2002, 83, 703.

(36) A. Hobson, R. G. Clark. Assessing avian diets using stable isotopes I: turnover of C-13 in tissues. Condor 1992a, 94, 181.

(37) K. A. Hobson, R. G. Clark. Assessing avian diets using stable isotopes II: Factors influencing diet-tissue fractionation. Condor 1992b, 94, 189.

(38) M. A. Vanderklift, S. Ponsard. Sources of variation in consumer-diet $\delta^{15} \mathrm{~N}$ enrichment: a meta-analysis. Oecologia, 2003,136,169.

(39) J. E. Soreide, T. Temalander, H. Hop, K. A. Hobson, I. Johansen. Sample preparation effects on stable $\mathrm{C}$ and $\mathrm{N}$ isotope values: a comparison of methods in Arctic marine food web studies. Mar. Ecol. Prog. Ser. 2006, 328, 17.

(40) D. M. Post, C. A. Layman, D. A. Arrington, G., Takimoto, J. Quattrochi, C. G. Montaña. Getting to the fat of the matter: models, methods, and assumptions for dealing with lipids in stable isotope analysis. Oecologia 2007, 152, 179.

(41) V. Lesage, Y. Morin, E. Rioux, C. Pomerleau, S.H. Ferguson, E. Pelletier E. Stable isotopes and trace elements as indicators of diet and habitat use in cetaceans: predicting errors related to preservation, lipid extraction, and lipid normalization. Mar. Ecol-Prog. Ser. 2010, 419, 249.

(42) P. E. Hare, M. L. Fogel, T.W. Stafford, A. D. Mitchell, T. C. Hoering. The isotopic composition of carbon and nitrogen in individual amino acids isolated from modern and fossil proteins. J. Archaeol. Sci. 1991, 18, 277.

(43) S. Todd, P.Ostrom, J. Lien, J. Abrajano. Use of biopsy samples of humpback whale (Megaptera novaeangliae) skin for stable isotopes $\left(\delta^{13} \mathrm{C}\right)$ determination. J. Northw. Atl. Fish. Sci. 1997, 22, 71.

(44) L. Z.Gannes, D. O’brien, C. Martínez Del Rio. Stable isotopes in animal ecology: assumptions, caveats, and a call for laboratory experiments. Ecology, 1997, 78, 1271.

(45) L. L. Tieszen, T. W. Boutton, K. G. Tesdahl, N. A. Slade. Fractionation and turnover of stable carbon isotopes in animal tissues: implications for $\delta^{13} \mathrm{C}$ analysis of diet. Oecologia 1983, 57, 32.

(46) J.N. Gearing. The study of diet and trophic relationships through natural abundance of ${ }^{13} \mathrm{C}$. in Carbon isotope techniques. (Eds: D.C. Coleman, B. Fry) Academic Press, San Diego. 1991, pp. 201-216.

(47) G.V. Hilderbrand, S.D. Farley, C.T. Robbins, T.A. Hanley, K. Titus, C. Servheen. Use of stable isotopes to determine diets of living and extinct bears. Can. J. Zool. 1996, 74, 2080.

(48) A. Aguilar, A. Borrell. Assessment of organochlorine pollutants in cetaceans by means of skin and hypodermic biopsies, in Nondestructive Biomarkers in Vertebrates (Eds: M. C. Fossi, C. Leonzio), Lewis Publishers, Boca Raton US, 1994, pp. 245. 


\section{TABLES:}

Table 1. Biological variables and sampled tissues of fin whales $(n=11)$

\begin{tabular}{|c|c|c|c|c|c|c|c|c|}
\hline Code & Sex & Length (m) & Skin & Bone & Liver & Kidney & Muscle & Brain \\
\hline 1 & male & 19.5 & * & * & * & * & * & * \\
\hline 2 & female & 18.9 & & * & * & * & * & \\
\hline 3 & male & 19.0 & * & * & * & * & * & \\
\hline 4 & male & 18.0 & * & * & * & * & * & * \\
\hline 5 & male & 15.0 & * & * & * & * & * & * \\
\hline 6 & female & 17.1 & * & & * & * & * & \\
\hline 7 & male & 17.8 & * & * & * & * & * & * \\
\hline 8 & male & 19.3 & * & * & * & & * & * \\
\hline 9 & male & 16.6 & * & * & * & * & * & \\
\hline 10 & female & 18.7 & * & * & * & * & * & * \\
\hline 11 & female & 18.5 & & * & * & * & * & * \\
\hline
\end{tabular}


Table 2. Stable isotope values for each tissue and krill-tissue fractionation factor $(\Delta)$ (mean \pm $\mathrm{SD})$

\begin{tabular}{|c|c|c|c|c|c|}
\hline Tissue & $\mathbf{n}$ & $\boldsymbol{\delta}^{15} \mathbf{N}(\%)$ & $\boldsymbol{\delta}^{13} \mathbf{C}(\%)$ & $\Delta^{15} \mathbf{N}$ & $\Delta^{13} \mathbf{C}$ \\
\hline Skin & $8 / 9$ & $9.97 \pm 0.30$ & $-18.29 \pm 0.38$ & $2.82 \pm 0.30$ & $1.28 \pm 0.38$ \\
\hline Muscle & 11 & $9.88 \pm 0.58$ & $-18.27 \pm 0.56$ & $2.73 \pm 0.58$ & $1.29 \pm 0.56$ \\
\hline Kidney & 10 & $10.63 \pm 0.85$ & $-18.04 \pm 0.42$ & $3.48 \pm 0.85$ & $1.53 \pm 0.42$ \\
\hline $\begin{array}{c}\text { Bone } \\
\text { protein }\end{array}$ & $9 / 10$ & $9.19 \pm 0.71$ & $-16.46 \pm 0.47$ & $2.03 \pm 0.71$ & $3.11 \pm 0.27$ \\
\hline Liver & 11 & $11.09 \pm 0.42$ & $-17.88 \pm 0.61$ & $3.94 \pm 0.42$ & $1.69 \pm 0.61$ \\
\hline Brain & $5 / 6$ & $11.42 \pm 0.36$ & $-17.35 \pm 0.51$ & $4.27 \pm 0.36$ & $2.22 \pm 0.51$ \\
\hline Baleen & 5 & $9.92 \pm 0.22$ & $-17.31 \pm 0.30$ & $2.77 \pm 0.22$ & $2.26 \pm 0.30$ \\
\hline
\end{tabular}


1

2

3

4

5

6

7

8

9

10

11

12

13

14

15

16

17

18

19

20

21

22

23

24

25

26

27

28

29

30

31

32

33

34

35

36

37

38

39

40

41

42

43

44

45

46

47

48

49

50

51

52

53

54

55

56

57

58

59

60

Table 3. Statistical differences in $\Delta^{15} \mathrm{~N}$ values (above the divide) and $\Delta^{13} \mathrm{C}$ values (below the divide) between tissues (n.s. non significant).

\begin{tabular}{|l|c|c|l|l|c|c|c|}
\hline$\Delta^{15} \mathrm{~N} / \Delta^{13} \mathrm{C}$ & Baleen & Skin & Liver & $\begin{array}{l}\text { Bone } \\
\text { protein }\end{array}$ & Kidney & Muscle & Brain \\
\hline Baleen & & n.s. & $\mathrm{p}<0.01$ & $\mathrm{p}<0.05$ & $\mathrm{p}<0.05$ & n.s. & $\mathrm{p}<0.01$ \\
\hline Skin & $\mathrm{p}<0.05$ & & $\mathrm{p}<0.01$ & $\mathrm{p}<0.05$ & $\mathrm{p}<0.05$ & n.s. & $\mathrm{p}<0.01$ \\
\hline Liver & n.s. & n.s. & & $\mathrm{p}<0.001$ & n.s. & $\mathrm{p}<0.01$ & n.s. \\
\hline Bone protein & $\mathrm{p}<0.05$ & $\mathrm{p}<0.001$ & $\mathrm{p}<0.01$ & & $\mathrm{p}<0.001$ & $\mathrm{p}<0.05$ & $\mathrm{p}<0.001$ \\
\hline Kidney & n.s. & n.s. & n.s. & $\mathrm{p}<0.01$ & & $\mathrm{p}<0.05$ & $\mathrm{p}<0.05$ \\
\hline Muscle & $\mathrm{p}<0.05$ & n.s. & n.s. & $\mathrm{p}<0.001$ & n.s. & & $\mathrm{p}<0.01$ \\
\hline Brain & n.s. & $\mathrm{p}<0.05$ & n.s. & $\mathrm{p}<0.05$ & n.s. & $\mathrm{p}<0.05$ & \\
\hline
\end{tabular}




\section{Figure Legends}

Figure 1. Relationship in the age of male $(n=55)$ and female $(n=10)$ individuals with (a) $\delta^{15} \mathrm{~N}(\% \circ)$ and (b) $\delta^{13} \mathrm{C}(\% \circ)$ values in muscle.

Figure 2. (a) $\delta^{15} \mathrm{~N}(\% \circ)$ and (b) $\delta^{13} \mathrm{C}(\%)$ fractionation factors plotted against tissue of the sampled fin whales $(n=11)$. Each individual is represented by a different colour. 
Figure 1

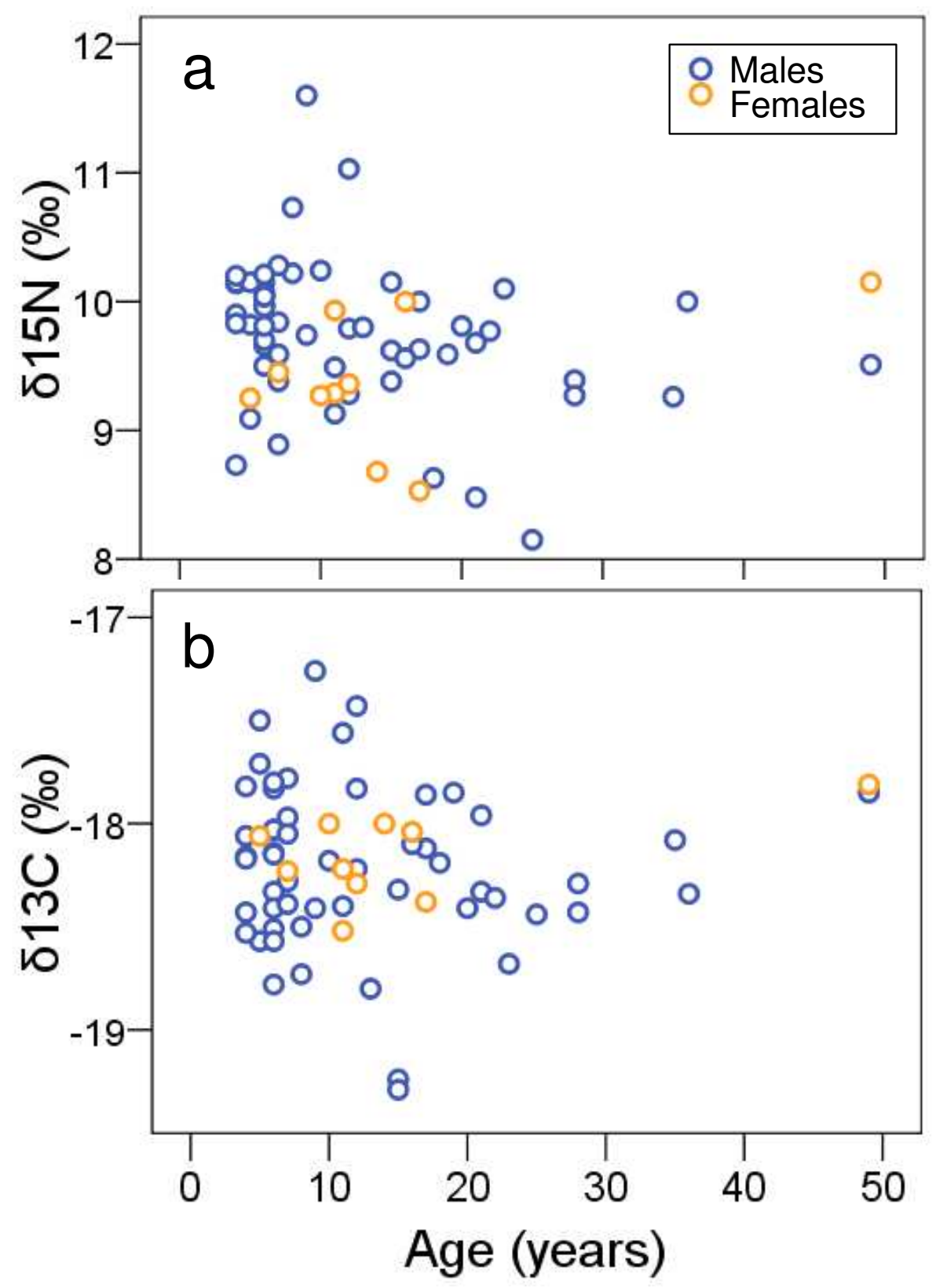

http://mc.manuscriptcentral.com/rcm 
Figure 2
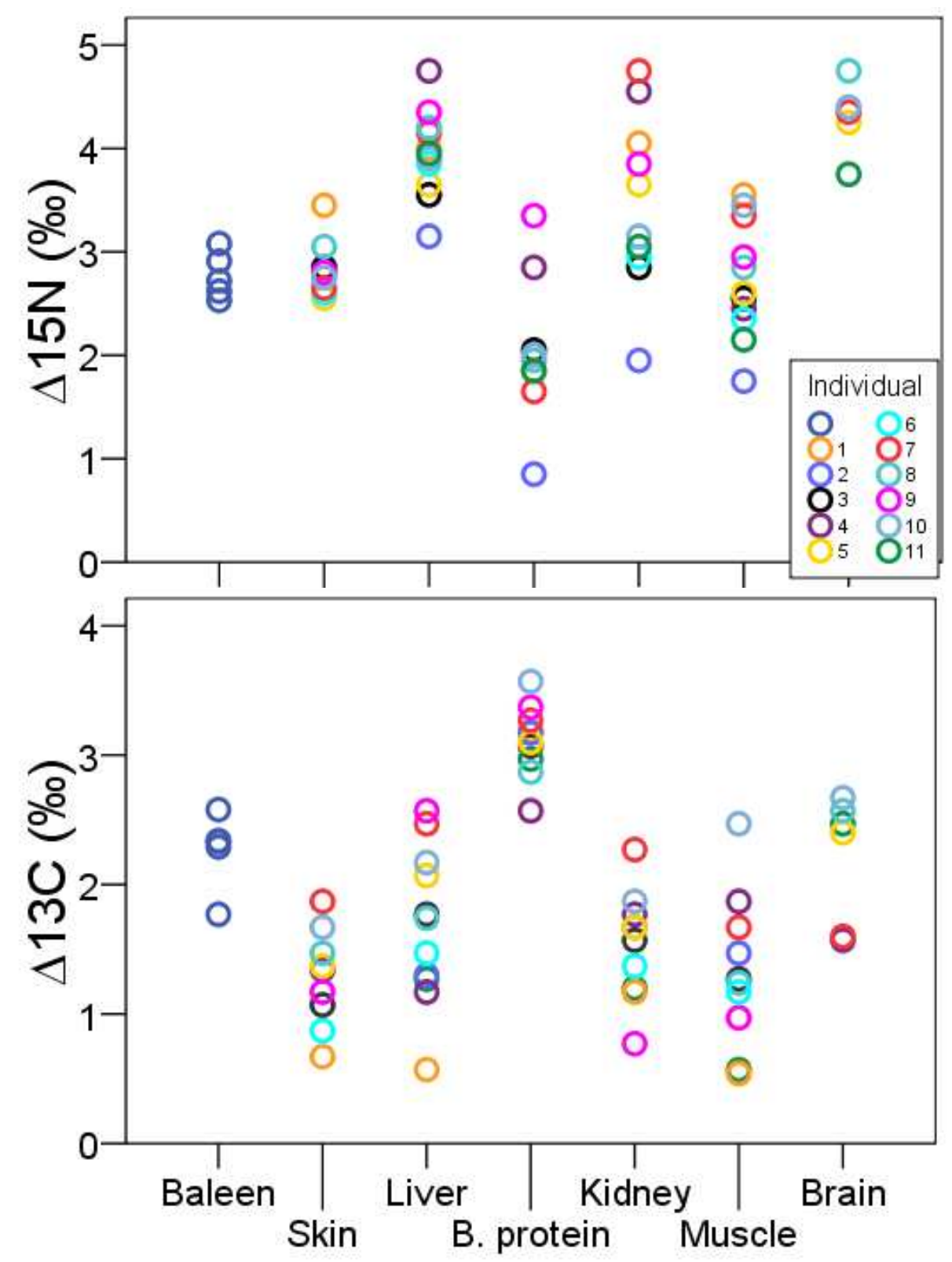

http://mc.manuscriptcentral.com/rcm 